\title{
Оцінка стоматологічного статусу дітей 6-7 років, які постійно проживають в умовах біогеохімічного дефіциту фтору та йоду
}

\author{
1 ДВНЗ «Ужгородський національний університет», м. Ужгород, Украӥна \\ ${ }^{2}$ Тернопільський національний медичний університет імені І.Я. Горбачевського, м. Тернопіль, Украӥна
}

\begin{abstract}
Об’єкт і методи дослідження. Був оцінений стоматологічний статус 73 школяра перших класах загальноосвітніх шкіл міста Ужгорода. Контрольну групу порівняння склали 26 здорових дітей аналогічного віку. Були визначені показники стоматологічної захворюваності за загальноприйнятими критеріями та проведені порівняння з показниками контрольної групи.

Результати. Встановлено достовірно вищу поширеніть карієсу у дітей клінічних груп у порівнянні з контрольною групою соматично здорових дітей ( $<<0,05)$; достовірно вищі показники карієсу тимчасових зубів у дітей клінічних груп $(p<0,05)$ та пломбованих постійних зубів $(p<0,05)$. Середні значення індексу OHI-S у дітей основних груп достовірно відрізнялися від показників контрольної групи $(p<0,01)$. Значення індексу Федорова-Володкіної достовірно перевишували значення даного індексу у дітей контрольної групи $(p<0,05)$. Значення індексу РМА у клінічних групах дітей було достовірно вищим, ніж у здорових дітей $(p<0,05)$. Найвищими показники індексу РМА були у третій групі дітей, які мали три загальносоматичні патології.

Висновки. У дітей молодшого шкільного віку Закарпатської області встановлено достовірно вищу поширеність та інтенсивність карієсу, гірший стан гігієни та наявність запалення ясен згідно з індексною оцінкою при соматичні патології у порівнянні з контрольною групою здорових дітей.
\end{abstract}

Ключові слова: поширеність та інтенсивність карієсу, діти, молодший шкільний вік, захворювання тканин пародонта.

Дана робота $є$ фрагментом НДР кафедри стоматології дитячого віку ДВНЗ «Ужгородський національний університет» «Комплексне обгрунтування надання стоматологічної допомоги дітям, які проживають в умовах біогеохімічного дефіциту фтору та йоду» (№ державної реєстрації 0119U101329).

\section{Вступ}

$\mathrm{B}$ исока поширеність карієсу постійних зубів у дітей в Україні [2, 11-16] висуває проблему профілактики як основну в дитячій стоматології. Зважаючи на те, що зуби після прорізування найбільш вразливі для ураження карієсом набуває особливої актуальності пошук нових підходів до створення програм профілактики карієсу постійних зубів, особливо на етапі незрілої емалі $[1,5,17]$.

Каріозний процес у зубах в перші роки після їх прорізування найчастіше розвивається в області фісур та природних заглиблень на жувальних поверхнях постійних зубів [1, 2, 5-10], що пояснюється низькою мінералізацією вказаної ділянки в цей період та складністю архітектоніки оклюзійних поверхнях, що створює несприятливі умови для їх очищення та сприяє виникненню фісурного карієсу [12-15].

Виникнення карієсу значною мірою обумовлюється i екологічними умовами, в яких мешкає дитина, а саме біогеохімічними дефіцитними мікроелементозами (особливо фтору, йоду, кальцію, магнію та ін.). До таких природних зон належить Закарпатська область, як природне середовище, в якому мешкає людина [2, 14-18]. Поширеність карієсу постійних зубів в 12-річних дітей

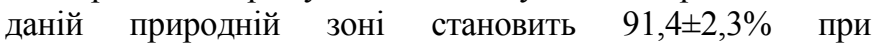

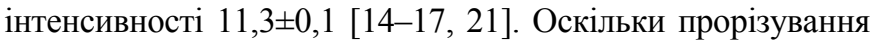
перших постійних молярів та стан незавершеної мінералізації співпадає 3 періодом підвищеного впливу стресу від адаптації організму дитини до школи, що знижує неспецифічну резистентність організму, проведення профілактичних заходів саме в цей період суттєво знижує ймовірність виникнення каріозних уражень у майбутньому.

Мета - визначення рівня стоматологічного здоров'я у дітей, які проживають в умовах біогеохімічно дефіцитних мікроелементозів у в період прорізування та мінералізації перших постійних молярів.

\section{Матеріали та методи}

Для встановлення рівня стоматологічного здоров'я дітей 6-7 років, які постійно проживають в умовах біогеохімічного дефіциту фтору та йоду був оцінений стоматологічний статус 73 дитини, мешканці міста Ужгорода, які навчаються в перших класах загальноосвітніх шкіл. Контрольну групу порівняння склали 26 дітей аналогічного віку, мешканців міста Ужгород вільних від карієсу, тобто здорових дітей. У дітей основної групи був визначений коефіцієнт обтяженості загальносоматичною патологією та був здійснений розподіл на підгрупи в залежності від показників.

Обстеження та лікування дітей було проведено в стоматологічних кабінетах клінічної бази кафедри 
стоматології дитячого віку ДВНЗ «Ужгородський національний університет». Всі діти відвідували загальноосвітні школи. Роботу розпочинали після отримання поінформованої згоди дітей та його батьків на участь у дослідженні.

Групу 1 склали 28 дітей $(53,6 \%-15$ хлопчиків та 46,4\% - 13 дівчаток), 6-7 років учнів загальноосвітніх шкіл м. Ужгород, в яких було верифіковано одну патологію (КОСП=1), до групи 2 входили 25 дітей $(48,0 \%-12$ хлопчиків та 52,0\% - 13 дівчаток) з верифікованими двома патологіями $($ КОСП=2), до 3 групи увійшли 20 дітей (50,0\% - 10 хлопчиків та 50,0\% - 10 дівчаток), які мали три патології $($ КОСП=3), при значенні КОСП>3 не враховувалися (табл. 1).

Контрольну групу склали 26 здорових дітей аналогічного віку, учнів загальноосвітніх шкіл міста Ужгород, які проходили диспансерний огляд без загальносоматичної патології (13 хлопчиків - 50,0\% та 13 дівчаток - 50,0\%).

Для визначення поширеності та інтенсивності основних стоматологічних захворювань в обстежених осіб користувались загальноприйнятими методами оцінки $[3,11,14]$. Поширеність карієсу визначали вираженими у відсотках відношення кількості хворих до загальної кількості обстежених. Для визначення інтенсивності карієсу в обстежених - за індексами кп, КПВ+кп [13].

Індексна оцінка стану гігієни та стану тканини пародонта у дітей клінічних груп. $\mathrm{y}$ дітей усіх обстежуваних груп було визначено гігієнічні індекси Федорова-Володкіної та спрощений індекс гігієни рота Green-Vermillion. За допомогою індексу гінгівіту PMА за Parma $[3,13]$ визначали ступінь запалення ясен у відсотках. Статистичний аналіз отриманих даних здійснювали 3 використанням загальноприйнятих методів математичної статистики 3 визначенням середнього значення, середнього квадратичного відхилення, похибки середньої величини, достовірності порівнюваних величин 3 визначенням параметричних та непараметричних критеріїв.

Методи описової статистики включали оцінку середнього арифметичного (C), інтервал достовірності (p), медіану (M), мінімум (min) та максимум (max), стандартне відхилення $\left(\sigma^{2}\right)$, асиметрю та ексцесс. Проаналізовано також парні і часткові кореляції Пірсона (r) із інтервалом достовірності (p), основаного на абсолютних даних. Усі обчислення проводилися на персональному комп'ютері 3 використанням ліцензованих програм "MS Excel 7" для операційної системи" Windows". та стандартного пакету програм «STATISTICA» v. 6.0.

Таблиця 1

Розподіл обстежених в залежності від статі

\begin{tabular}{|l|c|c|c|c|c|c|}
\hline \multirow{2}{*}{ Групи обстежених } & \multicolumn{2}{|c|}{ Всього } & \multicolumn{2}{c|}{ Хлопчики } & \multicolumn{2}{c|}{ Дівчатка } \\
\hline Група 1 & абс. & $\mathbf{\%}$ & $\mathbf{a б c . ~}$ & $\mathbf{\%}$ & $\mathbf{a б c . ~}$ & \% \\
\hline Група 2 & 28 & $30,8 \pm 4,83$ & 15 & $53,6 \pm 9,42$ & 13 & $46,4 \pm 9,42$ \\
\hline Група 3 & 25 & $27,5 \pm 4,68$ & 12 & $48,0 \pm 9,99$ & 13 & $52,0 \pm 9,99$ \\
\hline Всього & 20 & $22,0 \pm 4,34$ & 10 & $50,0 \pm 11,18$ & 10 & $50,0 \pm 11,18$ \\
\hline 3дорові діти & 73 & $100,0 \pm 0,0$ & 37 & $50,7 \pm 5,23$ & 36 & $49,3 \pm 5,23$ \\
\hline
\end{tabular}

\section{Результати дослідження та їх обговорення}

Оцінка стоматологічного статусу дітей 6-7 років, які постійно проживають в умовах біогеохімічного дефіциту фтору та йоду включала поширеність, інтенсивність та активність карієсу (табл. 2, 3).

При оцінці поширеності та інтенсивності карієсу у обстежених дітей встановлено, достовірно вищу поширеність карієсу у дітей клінічних груп у порівнянні 3 контрольною групою соматично здорових дітей $(88,6 \pm 5,60 ; \quad 93,2 \pm 3,80 ; \quad 96,4 \pm 1,98 ; \quad 65,3 \pm 2,89 ; \quad \mathrm{p}<0,05)$. Показники інтенсивності карієсу було достовірно вищими у дітей при наявності більше двох соматичних патологій $(8,6 \pm 0,23 ; 14,8 \pm 0,18 ; 4,1 \pm 0,23 ; \mathrm{p}<0,05)$.

Аналіз структури інтексу кпв+КП у обстежених дітей встановив достовірно вищі показники карієсу тимчасових зубів у дітей клінічних груп $(3,1 \pm 0,13 ; 3,7 \pm 0,05$; $5,2 \pm 0,16 ; 1,1 \pm 0,01 ; \mathrm{p}<0,05)$ та пломбованих постійних зубів $(0,5 \pm 0,01 ; 1,1 \pm 0,01 ; 2,6 \pm 0,11 ; 0,2 \pm 0,01 ; p<0,05)$ у порівнянні 3 контрольною групою здорових дітей. Показники пломбованих та видалених тимчасових зубів і каріозних постійних зубів достовірно не відрізняються у пацієнтів 3 однією патологією та в контрольній групі (p>0,05). Кількість каріозних постійних зубів у пацієнтів другої та третьої груп відрізнялися достовірно $(1,9 \pm 0,23 ; 3,4 \pm 0,12$; $0,4 \pm 0,01 ; \mathrm{p}<0,01)$ (табл. 4,5 ).

При оцінці ступеню активності карієсу у дітей клінічних та контрольної груп було встановлено достовірно нижчий відтсоток здорових від карієсу дітей $(\mathrm{p}<0,01)$ та вищий відсоток компенсованої активності карієсу $(\mathrm{p}<0,05)$.

При оцінці ступеню активності карієсу у дітей клінічних груп встановлено, що у 17 дітей $(65,4 \pm 0,51 \%)$ контрольної групи карієс був відсутній, та у 9 дітей $(34,6 \pm 0,21 \%)$ карієс був компенсованим, що достовірно відрізняється від показників основних груп, де найвищий відсоток декомпенсованого карієсу був у дітей 3 групи $45,0 \pm 3,1 \%$, нижчий - у другій групі - 32,0 $2,33 \%$, і досить

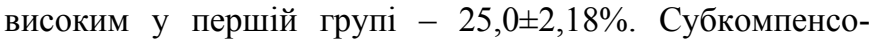
ваниий ступінь активності карієсу був досить високим у всіх клінічних групах $(39,3 \pm 1,23 \% ; \quad 36,0 \pm 3,61 \%$; $35,0 \pm 1,92 \%)$. 
Середнс значення індексу OHI-S у дітей першої групи становило $1,8 \pm 0,45$ балів; у дітей другої групи

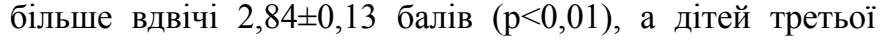

групи - в чотири рази $(3,00 \pm 0,18$ балів; $p<0,01)$, ніж у дітей

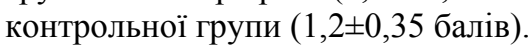

Таблиия 2

Поширеність та інтенсивність каріссу в клінічних групах

\begin{tabular}{|l|c|c|}
\hline \multicolumn{1}{|c|}{ Клінічні групи } & Поширеність каріссу (\%) & Інтенсивність каріссу (КПВ+кп) \\
\hline Група $1(\mathrm{n}=28)$ & $88,6 \pm 5,60^{*}$ & $5,3 \pm 0,20$ \\
\hline Група $2(\mathrm{n}=25)$ & $93,2 \pm 3,80^{*}$ & $8,6 \pm 0,23^{*}$ \\
\hline Група $3(\mathrm{n}=20)$ & $96,4 \pm 1,98^{*}$ & $14,8 \pm 0,18^{*}$ \\
\hline Здорові діти $(\mathrm{n}=26)$ & $65,3 \pm 2,89$ & $4,1 \pm 0,23$ \\
\hline
\end{tabular}

* - відмінності достовірні стосовно даних здорових дітей $(\mathrm{p}<0,05)$.

Табличя 3

Структура індексу інтенсивності каріссу у обстежених дітей

\begin{tabular}{|c|c|c|c|c|c|}
\hline \multirow{2}{*}{ Клінічні групи } & \multicolumn{5}{|c|}{ Структура КПВ+кп } \\
\hline & к & II & B & $\mathbf{K}$ & П \\
\hline Група 1 (n = 28) & $3,1 \pm 0,13^{*}$ & $0,8 \pm 0,04$ & $0,3 \pm 0,1$ & $0,6 \pm 0,12$ & $0,5 \pm 0,01 *$ \\
\hline Група $2(\mathrm{n}=25)$ & $3,7 \pm 0,05 * * *$ & $1,1 \pm 0,8^{*}$ & $0,8 \pm 0,07 *$ & $1,9 \pm 0,23 * * *$ & $1,1 \pm 0,01 * * *$ \\
\hline Група $3(\mathrm{n}=20)$ & $5,2 \pm 0,16 * * *$ & $2,6 \pm 0,16^{*}$ & $1,0 \pm 0,02 * * *$ & $3,4 \pm 0,12 * * *$ & $2,6 \pm 0,11 * * *$ \\
\hline Здорові діти (n = 26) & $1,1 \pm 0,01$ & $2,1 \pm 0,14$ & $0,3 \pm 0,02$ & $0,4 \pm 0,01$ & $0,2 \pm 0,01$ \\
\hline
\end{tabular}

* - відмінності достовірні стосовно даних здорових дітей $(\mathrm{p}<0,05)$;

** - відмінності достовірні стосовно даних здорових дітей $(\mathrm{p}<0,01)$.

Таблиия 4 Перебіг каріссу у обстежених дітей

\begin{tabular}{|c|c|c|c|c|c|}
\hline \multirow{2}{*}{\multicolumn{2}{|c|}{ Стан твердих тканин зубів }} & \multicolumn{2}{|c|}{ Діти клінічних груп (73 особи) } & \multicolumn{2}{|c|}{ Контрольна група (26 осіб) } \\
\hline & & абс. & $\%$ & абс. & $\%$ \\
\hline Карієс відсутній & & 5 & $6,8 \pm 0,01$ & 17 & $65,4 \pm 0,51$ \\
\hline \multirow{3}{*}{ Перебіг карієсу } & Компенсований & 11 & $15,1 \pm 0,51^{*}$ & 9 & $34,6 \pm 0,21$ \\
\hline & Субкомпенсований & 34 & $46,6 \pm 2,07$ & - & - \\
\hline & Декомпенсований & 23 & $31,5 \pm 1,08$ & - & - \\
\hline \multicolumn{2}{|l|}{ Разом } & 73 & $100,0 \pm 0,00$ & 26 & $100,0 \pm 0,00$ \\
\hline
\end{tabular}

* - відмінності достовірні стосовно даних здорових дітей $(\mathrm{p}<0,05)$.

Табличя 5

Показники активності карієсу у обстежених дітей

\begin{tabular}{|c|c|c|c|c|c|c|c|c|}
\hline \multirow{2}{*}{$\begin{array}{c}\text { Ступінь } \\
\text { активності каріссу }\end{array}$} & \multicolumn{2}{|c|}{ Група $1(n=28)$} & \multicolumn{2}{|c|}{ Група $2(n=25)$} & \multicolumn{2}{|c|}{ Група $3(n=20)$} & \multicolumn{2}{|c|}{ Здорові (n = 26) } \\
\hline & абс. & $\%$ & аб. & $\%$ & абс. & $\%$ & абс. & $\%$ \\
\hline Карієс відсутній & 3 & $10,7 \pm 0,6^{*}$ & 1 & $4,0 \pm 0,80^{*}$ & 1 & $5,0 \pm 1,08^{*}$ & 17 & $65,4 \pm 0,51$ \\
\hline Компенсований & 7 & $25,0 \pm 1,18$ & 7 & $28,0 \pm 1,91$ & 3 & $15,0 \pm 1,81 *$ & 9 & $34,6 \pm 0,21$ \\
\hline Субкомпенсований & 11 & $39,3 \pm 1,23$ & 9 & $36,0 \pm 3,61$ & 7 & $35,0 \pm 1,92$ & - & - \\
\hline Декомпенсований & 7 & $25,0 \pm 2,18$ & 8 & $32,0 \pm 2,33$ & 9 & $45,0 \pm 3,1$ & - & - \\
\hline
\end{tabular}

* - достовірність відмінностей у порівнянні з групою здорових дітей $(p<0,05)$.

Середнє значення індексу Федорова-Володкіної у дітей першої групи 1,73 $\pm 0,73$ балів; у дітей другої групи -

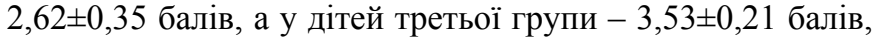

що достовірно перевищувало значення даного індексу у дітей контрольної групи $(1,42 \pm 0,16$ балів; $\mathbf{p}<0,05)$ (табл. 6). 
Табличя 6

Показники індексної оцінки гігісни в залежності від активності каріссу у дітей клінічних груп та у здорових дітей

\begin{tabular}{|c|c|c|c|c|c|}
\hline \multirow{2}{*}{\multicolumn{2}{|c|}{ Активність каріссу }} & \multicolumn{3}{|c|}{ Показники індексу I.G. Green, I.R.Vermillion } & \multirow{2}{*}{$\begin{array}{c}\text { Показники індексу } \\
\text { Федорова-Володкіної }\end{array}$} \\
\hline & & OHI-S & DI-S & CI-S & \\
\hline \multirow{5}{*}{ 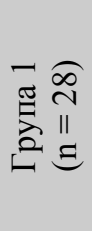 } & Карієс відсутній & - & - & - & - \\
\hline & Компенсований & $1,56 \pm 0,33$ & $1,3 \pm 0,45$ & $0,26 \pm 0,2 *$ & $1,62 \pm 0,03$ \\
\hline & Субкомпенсований & $1,85 \pm 0,32$ & $1,5 \pm 0,32$ & $0,35 \pm 0,32 *$ & $1,75 \pm 0,08$ \\
\hline & Декомпенсований & $2,01 \pm 0,71$ & $1,61 \pm 0,87$ & $0,4 \pm 0,56^{*}$ & $1,84 \pm 0,11$ \\
\hline & Середнє значення & $1,8 \pm 0,45$ & $1,47 \pm 0,54$ & $0,34 \pm 0.36^{*}$ & $1,73 \pm 0,73$ \\
\hline \multirow{5}{*}{ 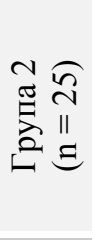 } & Карієс відсутній & - & - & - & - \\
\hline & Компенсований & $2,32 \pm 0,22 *$ & $1,42 \pm 0,04^{*}$ & $0,9 \pm 0,4^{*}$ & $2,34 \pm 0,45$ \\
\hline & Субкомпенсований & $2,85 \pm 0,03 *$ & $1,65 \pm 0,03 *$ & $1,2 \pm 0,03^{*}$ & $2,67 \pm 0,6$ \\
\hline & Декомпенсований & $2,35 \pm 0,3^{*}$ & $0,9 \pm 0,53 *$ & $1,45 \pm 0,07^{*}$ & $2,86 \pm 0,02$ \\
\hline & Середнє значення & $2,84 \pm 0,13^{*}$ & $2,65 \pm 0,2 *$ & $1,18 \pm 0,16^{*}$ & $2,62 \pm 0,35$ \\
\hline \multirow{5}{*}{ 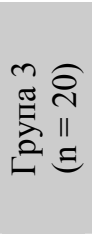 } & Карієс відсутній & - & - & - & - \\
\hline & Компенсований & $2,98 \pm 0,25^{*}$ & $1,36 \pm 0,03 *$ & $1,62 \pm 0,47^{*}$ & $2,9 \pm 0,05^{*}$ \\
\hline & Субкомпенсований & $2,95 \pm 0,27 *$ & $1,68 \pm 0,23 *$ & $1,27 \pm 0,34^{*}$ & $3,4 \pm 0,04 *$ \\
\hline & Декомпенсований & $3,00 \pm 0,03 *$ & $1,98 \pm 0,02 *$ & $1,02 \pm .0,03 *$ & $4,3 \pm 0.45 *$ \\
\hline & Середнє значення & $3,00 \pm 0,18^{*}$ & $1,98 \pm 0,7 *$ & $1,02 \pm 0,28 *$ & $3,53 \pm 0,21 *$ \\
\hline \multirow{5}{*}{ 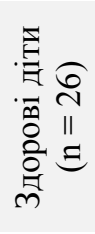 } & Карієс відсутній & $0,93 \pm 0,06$ & $0,9 \pm 0,02$ & $0,03 \pm 0,04$ & $1,24 \pm 0,04$ \\
\hline & Компенсований & $1,04 \pm 0,78$ & $0,98 \pm 0,7$ & $0,06 \pm 0,08$ & $1,38 \pm 0,07$ \\
\hline & Субкомпенсований & $1,28 \pm 0,48$ & $1,2 \pm 0,08$ & $0,08 \pm 0,4$ & $1,45 \pm 0,23$ \\
\hline & Декомпенсований & $1,56 \pm 0,07$ & $1,43 \pm 0,04$ & $0,13 \pm 0,03$ & $1,62 \pm 0,3$ \\
\hline & Середнє значення & $1,2 \pm 0,35$ & $1,13 \pm 0,21$ & $0,08 \pm 0,11$ & $1,42 \pm 0,16$ \\
\hline
\end{tabular}

Таблиия 7 контольної групи зі здоровим пародонтом. Відсоток

Показники індексу РМА у дітей клінічних груп та у здорових дітей

\begin{tabular}{|l|c|}
\hline \multicolumn{1}{|c|}{ Групи дослідження } & РМА, \% \\
\hline Група $1(\mathrm{n}=28)$ & $14,0 \pm 0,84$ \\
\hline Група $2(\mathrm{n}=25)$ & $45,0 \pm 1,20^{*}$ \\
\hline Група $3(\mathrm{n}=20)$ & $54,3 \pm 1,39 *$ \\
\hline Здорові $(\mathrm{n}=26)$ & $9,4 \pm 0,06$ \\
\hline
\end{tabular}

* - достовірність відмінностей у порівнянні

з групою здорових дітей $(\mathrm{p}<0,05)$.

Значення індексу РМА у клінічних групах дітей було достовірно вищим, ніж у здорових дітей $(14 \pm 0,84 \%$; $45,0 \pm 1,2 \% ; 54,3 \pm 1,39 \% ; \mathrm{p}<0,05)$. Найвищими показники індексу РМА були у третій групі дітей, які мали три загальносоматичні патології $(54,3 \pm 1,39 \%)$; трохи нижчими

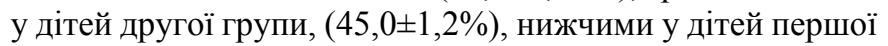
групи $(14 \pm 0,84 \%)$. Відповідно, у дітей контрольної та першої груп відмічався легкий ступінь гінгівіту, у дітей другої групи - середній, а у дітей третьої груп групи тяжкий ступінь гінгівіту.

Оцінка стану тканин пародонту у обстежуваних дітей представлена в таблиці 8. Нормальний стан тканин пародонта у дітей клінічних груп $(32,1 \pm 8,82 \% ; 20,0 \pm 8,1 \%$; $0,0 \pm 0,0 \% ; \mathrm{p}<0,05)$ був достовірно нижчий, ніж у дітей поширеності хронічного катарального гінгівіту у дітей клінічних груп $(67,9 \pm 8,82 \% ; 80,0 \pm 8,1 \% ; \quad 100,0 \pm 0,0 \%$; $\mathrm{p}<0,05)$. Поширеність легкого ступеню хронічного катарального гінгівіту у дітей досліджуваних груп $(67,9 \pm 8,82 \% ; 28,0 \pm 8,97 \% ; 25,0 \pm 9,68 \% ; \mathrm{p}<0,05)$ достовірно

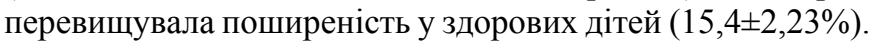
Середньотяжкий ступінь хронічного катарального гінгівіту діагностувався у 8 дітей другої $(32, \pm 9,32 \%)$, у 4 дітей третьої $(20,0 \pm 8,94 \%)$ груп; тяжкий ступінь - у 8 дітей другої (32, $\pm 9,32 \%)$ та у 8 дітей третьої (40,0 0 8,94\%) груп; загострення хронічного гінгівіту - у 2 дітей $(8,0 \pm 5,42 \%)$ другої та у 3 дітей третьої $(15,0 \pm 2,4 \%)$ груп, що не спостерігалося у здорових дітей $(\mathrm{p}>0,05)$.

Встановлено, найбільш обтяжена захворюваннями тканин пародонта третя клінічна група дітей, у 100\% яких відмічено хронічний катаральний гінгівіт у порівнянні зі здоровим пародонтом дітей контрольної групи $(\mathrm{p}<0,05)$, зокрема превалювання тяжкого $(40,0 \pm 8,94 \%-8$ осіб), легкого $(25,0 \pm 9,68 \%$ - 5 осіб), та середньотяжкого $(20,0 \pm 8,94 \%$ - 4 особи) ступенів тяжкості, у 3 осіб відмічено загострення гінгівіту $(15,0 \pm 2,4 \%)$.

$\mathrm{У}$ дітей другої групи при порівнянні зі здоровими дітьми нормального пародонта у $(20,0 \pm 8,1 \%$; $<<0,05)$, достовірне збільшення відсотка хронічного катарального гінгівіту $(80,0 \pm 8,1 \% ; \quad \mathrm{p}<0,05)$ за рахунок легкого ступеню тяжкості $(28,0 \pm 8,97 \%$; $<<0,05)$, середньотяжкого 
$(32, \pm 9,32 \%)$, тяжкого $(32,0 \pm 9,32 \%)$ ступеню хронічного катарального гінгівіту та загострення $(8,0 \pm 5,42 \%)$ хронічного катарального гінгівіту, що не спостерігалося у здорових.

Отже, при встановленні стану стоматологічного здоров'я 73 дітей 6-7 років, які постійно проживають в умовах біогеохімічного дефіциту фтору та йоду, та $є$ мешканцями міста Ужгорода, і навчаються в перших класах загальноосвітніх шкіл. Контрольну групу порівняння склали 26 здорових дітей аналогічного віку, мешканців міста Ужгород. Роботу розпочинали після отримання поінформованої згоди дітей та його батьків на участь у дослідженні.
У дітей основної групи був визначений коефіцієнт обтяженості загальносоматичною патологією та був здійснений розподіл на три підгрупи в залежності від показників. Групу 1 склали 28 дітей $(53,6 \%$ - 15 хлопчиків та 46,4\% - 13 дівчаток), 6-7 років учнів загальноосвітніх шкіл міста Ужгород, в яких було верифіковано одну патологію (КОСП=1), до групи 2 входили 25 дітей $(48,0 \%$ - 12 хлопчиків та $52,0 \%$ - 13 дівчаток) 3 верифікованими двома патологієями (КОСП=2), до 3 групи увійшли 20 дітей $(50,0 \%-10$ хлопчиків та $50,0 \%$ - 10 дівчаток), які мали три патології (КОСП=3), при значенні КОСП>3 не враховувалися.

Табличя 8

Стан тканин пародонта у обстежуваних дітей

\begin{tabular}{|c|c|c|c|c|c|c|c|}
\hline \multirow{3}{*}{\multicolumn{2}{|c|}{$\begin{array}{c}\text { Групи } \\
\text { спостереження }\end{array}$}} & \multirow{4}{*}{$\begin{array}{c}\text { Норма } \\
9 \\
9\end{array}$} & \multicolumn{5}{|c|}{ Хронічний катаральний гінгівіт } \\
\hline & & & \multirow{3}{*}{$\begin{array}{c}\text { Всього } \\
19\end{array}$} & \multicolumn{3}{|c|}{ Ступінь тяжкості } & \multirow{3}{*}{$\begin{array}{c}\text { Загострення } \\
-\end{array}$} \\
\hline & & & & \multirow{2}{*}{$\begin{array}{c}\text { легкий } \\
19\end{array}$} & \multirow{2}{*}{$\begin{array}{c}\text { середньо- } \\
\text { тяжкий } \\
-\end{array}$} & \multirow{2}{*}{$\begin{array}{c}\text { тяжкий } \\
\text { - }\end{array}$} & \\
\hline Група 1 & абс. & & & & & & \\
\hline$(n=28)$ & $\%$ & $32,1 \pm 8,82 *$ & $67,9 \pm 8,82^{*}$ & $67,9 \pm 8,82^{*}$ & - & - & - \\
\hline \multirow{2}{*}{$\begin{array}{l}\text { Група } 2 \\
(\mathrm{n}=25)\end{array}$} & абс. & 5 & 20 & 7 & 8 & 8 & 2 \\
\hline & $\%$ & $20,0 \pm 8,1 *$ & $80,0 \pm 8,1^{*}$ & $28,0 \pm 8,97^{*}$ & $32, \pm 9,32$ & $32, \pm 9,32$ & $8,0 \pm 5,42$ \\
\hline \multirow{2}{*}{$\begin{array}{l}\text { Група } 3 \\
(\mathrm{n}=20)\end{array}$} & абс. & - & 20 & 5 & 4 & 8 & 3 \\
\hline & $\%$ & - & $100,0 \pm 0,0^{*}$ & $25,0 \pm 9,68^{*}$ & $20,0 \pm 8,94$ & $40,0 \pm 8,94$ & $15,0 \pm 2,4$ \\
\hline \multirow{2}{*}{$\begin{array}{l}\text { Здорові } \\
(\mathrm{n}=26)\end{array}$} & абс. & 26 & - & - & - & - & - \\
\hline & $\%$ & $100,0 \pm 0,0$ & - & - & - & - & - \\
\hline
\end{tabular}

* - достовірність відмінностей у порівнянні з групою здорових дітей $(\mathrm{p}<0,05)$.

При оцінці поширеності та інтенсивності карієсу у обстежених дітей встановлено, достовірно вищу поширеніть карієсу у дітей клінічних груп у порівнянні 3 контрольною групою соматично здорових дітей $(88,6 \pm 5,60 ; \quad 93,2 \pm 3,80 ; \quad 96,4 \pm 1,98 ; \quad 65,3 \pm 2,89 ; \quad \mathrm{p}<0,05)$. Показники інтенсивності карієсу було достовірно вищими у дітей при наявності більше двох соматичних патологій $(8,6 \pm 0,23 ; 14,8 \pm 0,18 ; 4,1 \pm 0,23 ; \mathrm{p}<0,05)$.

Аналіз структури інтексу кпв+КП у обстежених дітей встановив достовірно вищі показники карієсу тимчасових зубів у дітей клінічних груп $(3,1 \pm 0,13$; $3,7 \pm 0,05 ; 5,2 \pm 0,16 ; 1,1 \pm 0,01 ; \mathrm{p}<0,05)$ та пломбованих постійних зубів $(0,5 \pm 0,01 ; 1,1 \pm 0,01 ; 2,6 \pm 0,11 ; 0,2 \pm 0,01$; $\mathrm{p}<0,05)$ у порівнянні 3 контрольною групою здорових дітей. Показники пломбованих та видалених тимчасових зубів і каріозних постійних зубів достовірно не відрізняються у пацієнтів 3 однією патологією та в контрольній групі ( $>>0,05)$. Кількість каріозних постійних зубів у пацієнтів другої та третьої груп відрізнялися достовірно $(1,9 \pm 0,23 ; 3,4 \pm 0,12 ; 0,4 \pm 0,01 ; \mathrm{p}<0,01)$.

При оцінці ступеню активності карієсу у дітей клінічних груп встановлено, що у 17 дітей $(65,4 \pm 0,51 \%)$ контрольної групи карієс був відсутній, та у 9 дітей $(34,6 \pm 0,21 \%)$ карієс був компенсованим, що достовірно відрізняється від показників основних груп, де найвищий відсоток декомпенсованого карієсу був у дітей 3 групи -

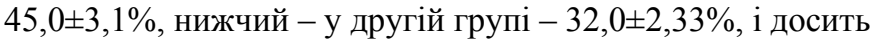

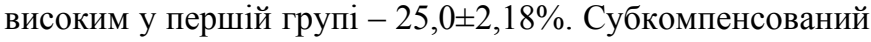
ступінь активності карієсу був досить високим у всіх клінічних групах $(39,3 \pm 1,23 \% ; 36,0 \pm 3,61 \% ; 35,0 \pm 1,92 \%)$.

Середні значення індексу OHI-S у дітей основних груп достовірно відрізнялися від показників контрольної групи $(1,8 \pm 0,45$ балів $(\mathrm{p}<0,05) ; 2,84 \pm 0,13$ балів; $3,00 \pm 0,18$ балів; $\mathbf{p}<0,01)$; у дітей контрольної групи $(1,2 \pm 0,35$ балів).

Значення індексу Федорова-Володкіної достовірно перевищували значення даного індексу у дітей контрольної групи $(1,73 \pm 0,73$ балів; 2,62 $\pm 0,35$ балів; $3,53 \pm 0,21$ балів; $1,42 \pm 0,16$ балів; $\mathrm{p}<0,05)$.

Значення індексу РМА у клінічних групах дітей було достовірно вищим, ніж у здорових дітей $(14 \pm 0,84 \%$; $45,0 \pm 1,2 \% ; 54,3 \pm 1,39 \% ; \mathrm{p}<0,05)$. Найвищими показники індексу РМА були у третій групі дітей, які мали три загальносоматичні патології $(54,3 \pm 1,39 \%)$.

\section{Висновки}

При аналізі захворюваності на карієс у дітей в період прорізування та мінералізації перших постійних молярів при різних ступенях активності карієсу 3 урахуванням регіональних особливостей Закарпатської області встановлено достовірно вищу поширеність та інтенсивність карієсу, рівень гігієни та наявність 
запалення ясен згідно індексної оцінки у дітей клінічних груп 3 наявними соматичним патологіями у порівнянні 3 контрольною групою соматично здорових дітей $(\mathrm{p}<0,05)$. Найгіршими були показники у третій групі дітей, які мали три загальносоматичні патології, що доводить наявність прямої залежності загальносоматичного та стоматологічного здоров’я у даних дітей.

\section{Перспективи подальших досліджень}

Встановлення рівня поширеності стоматологічних патологій у дітей молодшого шкільного віку дозволяє визначити напрямки проведення лікувальнопрофілактичних заходів, спрямованих на покращення рівня стоматологічного здоров'я.

\section{Література}

1. Безвушко Е.В. Структурно-функціональна резистентність емалі у дітей, які проживають у різних умовах навколишнього середовища / Е.В. Безвушко // Український стоматологічний альманах. - 2014. - № 3. - С. 9-11.

2. Біденко Н.В. Лікування карієсу зубів у дітей раннього віку: кроки до успіху. Частина 1. 3 чого почати? / Н.В. Біденко // Дента клуб. - 2013. - № 7-8. - С. 6-8.

3. Виноградова Т.Ф. Диспансеризация детей у стоматолога. - М., 1987. -255 с.

4. Гасюк Н.В. Структура та поширеність хвороб пародонта у осіб молодого віку / Н.В. Гасюк // Південноукраїнський медичний журнал. - 2013. - № 3 (03). - С. 36-37.

5. Задорожна I.B. Поширеність та інтенсивність карієсу зубів у дітей України: результати клінікоепідеміологічного обстеження / І.В. Задорожна, В.В. Поворозюк // Боль. Суставы. Позвоночник [Електронний ресурс] Режим доступу: http://www.mif-ua.com/archive/article/38691.

6. Казакова Р. В. Пропедевтика дитячої терапевтичної стоматології / Р. В. Казакова, М. А. Лучинський, М. Воляк [та ін.], 2-ге вид., випр. - К.: Медицина, 2011. - 271 с.

7. Казакова Р.В. Порівняльний аналіз показників карієсу зубів і захворювань тканин пародонта у підлітків, які проживають в різних екологічних умовах / Р.В. Казакова, Л.В. Білищук, В.С. Мельник // Новини стоматології. 2013. - № 1. - С. 78-79.

8. Каськова Л.Ф. Епідеміологічні дослідження - основа планування заходів профілактики стоматологічних хвороб у дітей / Л.Ф. Каськова, Н.В. Левченко, О.Ю. Андріанова [та ін.] // Український стоматологічний альманах. 2011. - № 2. - С. 25-26.

9. Каськова Л.Ф. Прогнозування поширеності карієсу в історичному аспекті / Л.Ф. Каськова, А.В. Артем’єв // Світ медицини і біології. - 2012. - № 4. - С. 26-28.

10. Каськова Л.Ф. Характеристика ураженості карієсом перших постійних молярів залежно від їх одонтогліфіки у дітей м. Полтави / Л.Ф. Каськова, Ю.І. Солошенко, Л.І. Амосова // Світ медицини та біології. - 2014. - № 3. C. 62-64.

11. Клітинська О.В. Матеріали докторської дисертації «Комплексне обгрунтування діагностики, профілактики та поетапного лікування карієсу у дітей, які постійно проживають в умовах біогеохімічного дефіциту фтору та йоду». - Полтава, 2015.

12. Клітинська О.В. Ранжування уражень карієсом зубів у дітей при ретроспективному аналізі первинної медичної документації / О.В. Клітинська, А.А. Васько // Україна. Здоров’я нації. - 2016. - № 3 (39). - С. 39-44.

13. Хоменко Л.А. Терапевтическая стоматология детского возраста / Л.А. Хоменко, Л.П. Кисельникова, Н.И. Смоляр. - К. : Книга Плюс. - 2013. - 864 с.

14. Klitinska O.V. Exogenus drug prevention of dental caries in primery school children with high caries activity / O.V. Klitinska, A.A. Vasko, Y.A. Mukhina // Intermedical journal. - 2016. - Vol. I (7). - P. 10-12.

15. Klitinska O.V. Efficiency estimation of using phased program of caries prevention in children domiciled in Transcarpathian region / O.V. Klitinska, Y.Y. Kostenko, Y.A. Mukhina, A.A. Vasko, N.V. Layosh // Acta stomatologica Naissi. - 2016. - Vol. 32, № 74. - P. 1635-1649. DOI: 10.5937/asnl674635K.

16. Klitinska O.V. Determination of criteria early caries diagnostics in children of different ethnic groups domiciled in biogeochemical deficiency of fluorine and iodine / O.V. Klitinska, Y.Y. Kostenko, V.R. Gurando // Journal of Stomatology. 2016. - Vol. 70 (1), Issue 1. - P. 51-56. DOI: 10.5604/01.3001.0010.1778.

17. Klitinska O.V. Statistical model of caries formation and progression in children of preschool and early school age domiciled in biogeochemical deficiency of fluorine and iodine / O.V. Klitinska, N. V. Gasyuk, Yeugen Y. Kostenko, Viacheslav R. Gurando // Journal of Stomatology. - 2017. - Vol. 70 (6), Issue 1. - P. 674-678 (Polish Dental Association) DOI: $10.5604 / 01.3001 .0010 .7725$.

18. Klitinska O.V. Clinical and Laboratory Grounds for the Rational Selection of Filling Material for the Restoration of Deciduous Teeth / O.V. Klitinska, Artur A Vasko, Volodymyr O Borodach, Natalia V Hasiuk, Larisa V Kornienko, Dmytro V Tsukanov // Pesquisa Brasileira em Odontopediatria e Clinica Integrada 2018, 18(1):e3949 DOI: http://dx.doi.org/10.4034/ PBOCI.2018.181.52 ISSN 1519-0501. -7 p. 
Оценка стоматологического статуса детей 6-7 лет, постоянно проживающих в условиях биогеохимического дефицита фтора и йода

Клитинская O.B. ${ }^{1}$, Стишковський A.B. ${ }^{1}$, Гасюк H.B. ${ }^{2}$

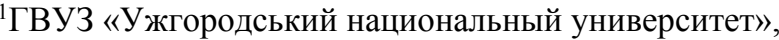
г. Ужгород, Украина

${ }^{2}$ Тернопольский национальный медицинский университет имени И.Я. Горбачевського, г. Тернополь, Украина.

Объект и методы исследования: был оценен стоматологический статус 73 школьника первых классов общеобразовательных школ Ужгорода. Контрольную группу сравнения составили 26 здоровых детей аналогичного вовзаста. Были определены показатели стоматологической заболеваемости по общепринятым критериям и сравнили с показателями контрольной группы.

Результаты: установлено достоверно више распрастраненность кариеса у детей клинических групп при сравнении с контрольной группою соматически здоровых детей $(\mathrm{p}<0,05)$; достоверно више показатели кариеса временных зубов $(p<0,05)$ и пломбованных постоянных зубов $(\mathrm{p}<0,05)$. Средние значения индекса OHI-S у детей основных групп достоверно отличались от показателей контрольной группы $(p<0,01)$. Значения индекса Федорова-Володкиной достоверно превышали значения в контрольной группе $(\mathrm{p}<0,05)$. Значения индекса РМА клинических групп детей достоверно више, чем у здоровых детей $(\mathrm{p}<0,05)$.

Выводы. У детей младшего школьного возраста Закарпатськой области установлено достоверно выше распрастраненность и интенсивность кариеса, хуже уровень гигиены и воспаления десен по индексной оценке у детей с соматическими патологиями по сравнению с контрольной группой здоровых детей.

Ключевые слова: распрастраненность и интенсивность кариеса, дети, младший школьный возраст, заболевания тканей пародонта.

Stomatological status evaluation of children 6-7 years old living in conditions of the biogochemical deficit of fluorine and iodine

\section{Oksana V. Klitynska ${ }^{1}$, Andriy V. Stishkovskyy ${ }^{2}$ Natalia V. Hasiuk}

${ }^{1}$ Professor, Head of the Department of Pediatric Dentistry, State Higher Educational Establishment Uzhhorod National University, Uzhhorod, Ukraine

${ }^{2}$ Postgraduate of the Faculty of Dentistry, State Higher Educational Establishment Uzhhorod National University, Uzhhorod, Ukraine

${ }^{3}$ Professor, Department of Terapeutic Dentistry, Horbachevsky Ternopil State Medical University, Ternopil, Ukraine

The aim of the study. Determination of the level of dental health among children living under conditions of biogeochemically deficient trace elements during the eruption and mineralization of the first permanent molars.

Object and research methods. The dental status of 73 first-grade pupils of Uzhhorod secondary schools was assessed. Group 1 consisted of 28 children $(53.6 \%-15$ boys and $46.4 \%-13$ girls), 6-7 years of pupils of Uzhhorod secondary schools who had one pathology verified (COPD = 1), group 2 included 25 children $(48.0 \%$ - 12 boys and $52.0 \%-13$ girls) with two pathologies verified $(\mathrm{COPD}=2)$, 3 rd group included 20 children $(50.0 \%-10$ boys and $50.0 \%-$ 10 girls) who had three pathologies $(\mathrm{COPD}=3)$ were not considered for $\mathrm{COPD}>3$. The comparison control group consisted of 26 healthy children of the same age. Dental morbidity indices were determined according to generally accepted criteria and comparisons were made with those of the control group. Statistical analysis of the obtained data was carried out using conventional methods of mathematical statistics with determination of mean value, mean square deviation, error of mean value, reliability of compared values with determination of parametric and non-parametric criteria. The examination and treatment of children were conducted in the dental offices of the clinical base of Dentistry Department of Pediatric Dentistry, Uzhhorod National University. All the children attended secondary schools. Work was started after informed consent of the children and their parents to participate in the study.

Results. When establishing the dental health status, 73 children aged 6-7, who are permanently living in conditions of biogeochemical deficiency of fluorine and iodine, are residents of the city of Uzhhorod, and are enrolled in the first grades of secondary schools. The comparison control group consisted of 26 healthy children of the same age, residents of Uzhhorod. Work was started after informed consent of the children and their parents to participate in the study.

Among children of the main group, the rate of burden with somatic pathology was determined and was divided into three subgroups depending on the indicators. Group 1 consisted of 28 children $(53.6 \%-15$ boys and $46.4 \%-13$ girls), 6-7 years of students of Uzhhorod secondary schools who had one pathology verified $(\mathrm{COPD}=1)$, group 2 included 25 children ( $48.0 \%-12$ boys and $52.0 \%-13$ girls) with two pathologies verified $($ COPD $=2)$, 3rd group included 20 children $(50.0 \%-10$ boys and $50.0 \%-10$ girls $)$ who had three pathologies $(\mathrm{COPD}=3)$ were not considered for $\mathrm{COPD}>3$.

When assessing the prevalence and intensity of caries in the examined children, it was found that the caries prevalence was significantly higher among children of the clinical groups compared to the control group of somatically healthy children $(88.6 \pm 5.60 ; 93.2 \pm 3.80 ; 96.4 \pm 1,98 ; 65.3 \pm 2.89$; $\mathrm{p}<0.05)$. The rates of caries intensity were significantly higher among children with more than two somatic pathologies $(8.6 \pm 0.23 ; 14.8 \pm 0.18 ; 4.1 \pm 0.23 ; \mathrm{p}<0.05)$.

Analysis of the structure of the intersection of $\mathrm{CSR}+\mathrm{CP}$ among examined children revealed significantly higher rates of temporary dental caries in children of clinical groups $(3.1 \pm 0.13 ; 3.7 \pm 0.05 ; 5.2 \pm 0.16 ; 1.1 \pm 0.01 ; \mathrm{p}<0.05)$ and fulltooth permanent teeth $(0.5 \pm 0.01 ; 1.1 \pm 0.01 ; 2.6 \pm 0.11$; $0.2 \pm 0.01 ; \mathrm{p}<0.05)$ compared with the control group of healthy 
children. The rates of sealed and removed temporary teeth and carious permanent teeth were not significantly different among patients with the same pathology and in the control group $(p>0.05)$. The number of carious permanent teeth in patients of the second and third groups differed significantly (1.9 \pm 0.23 ; $3.4 \pm 0.12 ; 0.4 \pm 0.01 ; \mathrm{p}<0.01)$. When evaluating the degree of caries activity among children of the clinical groups, it was found that 17 children $(65.4 \pm 0.51 \%)$ of the control group had no caries, and 9 children $(34.6 \pm 0.21 \%)$ caries were compensated that significantly different from the indicators of the main groups, where the highest percentage of decompensated caries was among children of group $3-$ $45,0 \pm 3,1 \%$, lower - in the second group - 32,0 $02,33 \%$, and quite high in the first group - 25,0 $2.18 \%$. The subcompensated degree of caries activity was quite high in all clinical groups $(39.3 \pm 1.23 \% ; 36.0 \pm 3.61 \% ; 35.0 \pm 1.92 \%)$.

The mean values of OHI-S index among children of the main groups were significantly different from those of the control group $(1.8 \pm 0.45$ points $(\mathrm{p}<0.05) ; 2.84 \pm 0.13$ points; $3.00 \pm 0.18$ points; $\mathrm{p}<0.01)$; in control children $(1.2 \pm 0.35$ points). The values of Fedorova-Volodkina index significantly exceeded the values of this index among children of the control group ( $1.73 \pm 0.73$ points; $2.62 \pm 0.35$ points; $3.53 \pm 0.21$ points; $1.42 \pm 0.16$ points; $\mathrm{p}<0,05)$.

The PMA index in the clinical groups of children was significantly higher compared to healthy children $(14 \pm 0.84 \%$; $45.0 \pm 1.2 \% ; 54.3 \pm 1.39 \% ; \mathrm{p}<0.05)$. The highest PMA indexes were in the third group of children who had three general somatic pathologies $(54.3 \pm 1.39 \%)$.

Conclusions. In the analysis of caries incidence among children during the eruption and mineralization of the first permanent molars at different degrees of caries activity, taking into account the regional features of the Transcarpathian region, significantly higher prevalence and intensity of caries, hygiene level and presence of gingival inflammation according to index groups pathologies compared with the control group of somatically healthy children $(\mathrm{p}<0.05)$. The worst situation was detected in the third group where children had three general somatic pathologies, which proves the direct dependence of somatic and dental health among these children.

Key words: prevalence and intensity of caries, children, elementary school age, periodontal tissue diseases.

\section{Відомості про авторів}

Клітинська Оксана Василівна - доктор медичних наук, професор, завідувач кафедрою стоматології дитячого віку Державного вищого навчального закладу «Ужгородський національний університет», м. Ужгород, Україна.

Стішковський Андрій Вікторович - аспірант кафедри стоматології дитячого віку Державного вищого навчального закладу «Ужгородський національний університет», м. Ужгород, Україна.

Гасюк Наталія Володимирівна - доктор медичних наук, доцент, професор кафедри терапевтичної стоматології Тернопільського національного медичного університету імені І.Я. Горбачевського МОЗ України, м. Тернопіль. 